\title{
CROSS-CORRELATION ANALYSIS OF THE SPATIAL INTERACTIONS BETWEEN TISSUE COMPARTMENTS OF THE RENAL CORPUSCLE
}

\author{
TERRY M MAYHEW \\ School of Biomedical Sciences, E Floor, University of Nottingham, Queen's Medical Centre, Nottingham NG7 \\ 2UH, UK \\ e-mail: terry.mayhew@nottingham.ac.uk \\ (Accepted October 9, 2002)
}

\begin{abstract}
The renal corpuscle is a multi-compartment unit of kidney morphology which is important for normal ultrafiltration of blood. Its structure is perturbed during ontogeny, disease and experimental manipulation. Transmission electron microscopy and second-order stereological tools (cross covariance and cross correlation functions) were used to examine 3-D spatial interactions between the main tissue compartments (glomerular capillaries, podocytes, mesangium, urinary space) of the renal corpuscle in normal adult rats. Volume densities, covariance and correlation functions were estimated by counting test points (randomly positioned) and linear dipole probes (randomly positioned and orientated) superimposed on random samples of photomontages prepared from ultrathin resin sections. Differences in clustering exist between compartments (at distances $<8 \mu \mathrm{m}$, mesangium is the most tightly-clustered and capillaries the least tightlyclustered compartment; $>8 \mu \mathrm{m}$, compartments are neither hypodisperse nor hyperdisperse). Despite this, cross correlation functions for linked sets of compartments (capillary-mesangium, capillary-podocytes, capillary-urinary space, mesangium-podocytes, mesangium-urinary space and podocytes-urinary space) did not vary with dipole distance. This indicates that the spatial relations between linked compartments do not favour attraction or repulsion. In addition, inter-individual variation is greater for some linked compartments than others. Variation is less for compartments (capillary-podocyte and capillary-urinary space) which contribute to the ultrafiltration barrier and this probably reflects the structural and functional integration evident at this site as well as the higher volume densities (and smaller inter-subject variation) for capillaries.
\end{abstract}

Keywords: cross correlation function, mesangium, podocytes, renal glomerular capillaries, second-order stereology, spatial arrangement, urinary space.

\section{INTRODUCTION}

Second-order stereological methods permit the quantitative description of 3-D spatial arrangements within and between different compartments from subcellular to organismal levels. Appropriate descriptors are available for quantifying variables which depend on spatial interactions and/or for testing whether or not relationships conform to some predicted (often random) pattern (Cruz-Orive, 1976, 1989; Serra, 1982; Gundersen and Jensen, 1985; Baddeley et al., 1987; Jackson et al., 1988; Evans and Gundersen, 1989; Vesterby et al., 1989; Jensen et al., 1990; Mattfeldt et al., 1993a,b, 1996; Mayhew and Wadrop, 1994; Stoyan et al., 1995; Mayhew, 1999a,b; Reed and Howard, 1998, 1999; Mayhew et al., 2000, 2002).

Analysis of set covariance, $\mathrm{C}[\mathrm{r}]$, and pair correlation functions, $\mathrm{g}[\mathrm{r}]$, has proved useful for testing whether or not the individual elements of structural compartments in cells and organs are clustered or hyperdisperse at defined distances (Mattfeldt et al., 1993a,b; Mayhew, 1999a,b; Reed and Howard, 1999). Such studies have adduced evidence that spatial arrangements at different levels of organisation are tightly maintained (exhibit low inter-subject coefficients of variation). However, relatively little attention has been afforded to studying interactions between compartments (Greco et al., 1979) and yet these can be explored by estimating cross covariances and correlation functions.

This investigation extends earlier work on renal corpuscles from untreated and chemically-induced diabetic rats (Mayhew, 1999b) by analysing cross covariances and correlation functions for different tissue compartments (glomerular capillaries, podocytes, mesangium and urinary space). It complements other recent approaches for analysing spatial arrangements within the kidney (e.g. Fricout et al., 2002) and provides normal baseline data which should prove useful for comparison with pathological and other material. 


\section{MATERIALS AND METHODS}

ANIMALS. Analyses are based on 23-weeks-old male Sprague Dawley rats $(n=9)$ with a mean body weight of $647 \mathrm{~g}$ (coefficient of variation, 6\%). Subjects were maintained on a $14 \mathrm{hr}: 10 \mathrm{hr}$ light:dark cycle and fed on a standard pellet diet with free access to drinking water. They were killed between $9.30 \mathrm{hr}$ and $12.30 \mathrm{hr}$ under ether anaesthesia. Tissues were fixed by intracardiac perfusion of an isotonic saline prewash followed by $2.5 \%$ glutaraldehyde in Millonig's phosphate buffer ( $\mathrm{pH}$ 7.2-7.4). Perfusions took place under gravity feed and at ambient temperature. Following fixation, kidneys were removed, freed of perinephric fat and weighed. Kidneys from one side only (mean weight $2.27 \mathrm{~g}$, CV 16\%) were taken for subsequent sampling and stereological analysis.

TISSUE SAMPLING. The basis of tissue selection was random sampling (see Mayhew, 1999b for details). Fixed kidneys were cut into roughly 1 mm thick slabs and diced into roughly $1 \mathrm{~mm}^{3}$ cubes. These were sampled by the lottery method, post-fixed in $1 \%$ phosphate-buffered osmium tetroxide, dehydrated in ethyl alcohol and processed for transmission electron microscopy with embedding in Araldite resin. Physical randomisation of tissue orientation was introduced by allowing diced kidney samples to settle haphazardly in embedding medium. Tissue blocks (1-2 per kidney) were selected by lottery for ultrathin sectioning (thickness ca. $70 \mathrm{~nm}$ ), contrasted with lead citrate and uranyl acetate, mounted on slot grids and examined using a Philips microscope operated at an accelerating voltage of $60 \mathrm{kV}$. Fields of view of corpuscular profiles were recorded and 2 entire profiles per kidney prepared as photomontages. Final print magnifications $(\times 3200)$ were calibrated using a carbon grating replica as an external standard.

STEREOLOGICAL ANALYSIS. Renal corpuscles are spheroidal structures with a diameter of roughly $110 \mu \mathrm{m}$ and comprising a branching network of capillaries (the glomerular tuft) lined internally by vascular endothelium resting on a basal lamina which is covered externally by myriad interdigitating processes of octopus-like podocytes. Podocytes lie in the urinary space. Mesangial cells also lie within the basal lamina but are separated from the capillary lumen by the vascular endothelium. Based on estimated mean cell volumes, the 'diameters' of endothelial and mesangial cells are about $6 \mu \mathrm{m}$ whilst the 'diameter' of a podocyte soma is about $10 \mu \mathrm{m}$ (Bertram, 1995). A diagram illustrating renal glomerular morphology has been provided in the earlier report (Mayhew, 1999b).
Prior to analysis, each renal corpuscle was delimited using the string polygon approach to circumscribe the capillaries and some, but not all, of the urinary space (Bertram, 1995). The definitions of structural ingredients of the corpuscle were the same as those employed previously (Mayhew, 1999b). The ultrafiltration barrier comprises glomerular capillary vascular endothelium, visceral epithelium (podocytes) and a shared basal lamina. Mesangium comprises mesangiocytes and a matrix which includes basement membrane-like material. Between the visceral epithelium and an outer parietal epithelium is the urinary space.

A test lattice was superimposed on each montage so as to be random in position and orientation. Each lattice comprised 4 parallel straight lines serving as a set of linear dipole probes (Reed and Howard, 1999). Each line was divided into 20 equidistant intervals each of which represented a distance of $3.97 \mu \mathrm{m}$ on the actual specimen. This distance is a sensible choice given the sizes of corpuscles and the different sorts of glomerular cells (Bertram, 1995; Mayhew, 1999b).

Each kidney was analysed using 8 trials (a total of 32 test lines and 672 test points) after each of which lattice orientation was altered systematically using equiangular increments of $37^{\circ}$ so as to avoid cycles of orientation repetition. The nature of the tissue compartment underlying each test point was noted and this was recorded on a $21 \times 32$ matrix (i.e. 672 cells) printed in tabular format. Within the cells of this matrix, each test point was coded as 0 (capillary), 1 (podocyte), 2 (mesangium) or 3 (urinary space). Analysis of these datasets was facilitated by using software for an algorithm run on a PC in a DOS window in Windows95 ${ }^{\mathrm{TM}}$ (Reed and Howard, 1999).

Volume densities (VV), covariances and correlation functions (Mattfeldt et al., 1993a) were derived for dipole distances varying from $r=0(0 \mu \mathrm{m})$ to $r=10$ $(39.7 \mu \mathrm{m})$. Higher distances were not recorded due to the size of the glomerulus, the nature of its structural symmetry and the fact that larger distances generated lower dipole counts and, hence, lower levels of precision. Values of $\mathrm{V}_{\mathrm{V}}$ for each tissue compartment were estimated by counting test points hitting the compartment and dividing by the total hitting the reference space (= corpuscle). For linked compartments (e.g. podocytes and mesangium), comparable volume densities were calculated using the square root of the product $\mathrm{V}_{\mathrm{Va}} \times \mathrm{V}_{\mathrm{Vb}}$ where $\mathrm{V}_{\mathrm{Va}}$ represents, say, the volume density of podocytes and $\mathrm{V}_{\mathrm{Vb}}$ that of mesangium. For estimating cross covariances $(\mathrm{C}[\mathrm{r}])$, the number of dipoles whose points hit two separate 
compartments (e.g. podocytes and mesangium) was divided by the total whose points hit the reference space. Cross correlation functions $(\mathrm{g}[\mathrm{r}])$ were obtained by dividing the corresponding values of $\mathrm{C}[\mathrm{r}]$ by $\mathrm{V}_{\mathrm{Va}} \times \mathrm{V}_{\mathrm{Vb}}$.

STATISTICS. Group means and observed coefficients of variation $(\mathrm{CV}=$ standard deviation expressed as a $\%$ of the corresponding mean) were calculated for tissue volume fractions, cross covariances and cross correlation functions. Calculations were made using the Unistat (version 4.53) statistical package.

\section{RESULTS}

On average, renal corpuscles comprised the following compartment volume densities (CV): glomerular capillaries 0.507 (15\%), mesangium 0.108 $(23 \%)$, podocytes $0.239(24 \%)$ and urinary space $0.146(28 \%)$. Analogous values (square root of $\mathrm{V}_{\mathrm{Va}} \times \mathrm{V}_{\mathrm{Vb}}$ ) for linked compartments were: capillarymesangium $0.232(13 \%)$, capillary-podocytes 0.343 (7\%), capillary-urinary space $0.267(12 \%)$, mesangiumpodocytes 0.159 (14\%), mesangium-urinary space $0.123(17 \%)$ and podocytes-urinary space $0.185(22 \%)$.
Table 1 provides the estimated values of $\mathrm{C}[\mathrm{r}]$ and $\mathrm{g}[\mathrm{r}]$ for the various linked compartments against dipole distances, r. In all cases, expected reference ('null hypothesis') values of $\mathrm{C}[\mathrm{r}]$ (expected value = $\left.\mathrm{V}_{\mathrm{Va}} \times \mathrm{V}_{\mathrm{Vb}}\right)$ and $\mathrm{g}[\mathrm{r}]($ expected value $=1)$ are provided.

Two principal findings emerge from these results. First, with the possible exception of the smallest dipole distances, the expected values of $\mathrm{C}[\mathrm{r}]$ and $\mathrm{g}[\mathrm{r}]$ correspond to those predicted for wholly random spatial interactions between compartments with given volume densities. The chosen linked compartments do not exhibit evidence of preferential attraction or repulsion over almost the whole range of dipole distances examined. Second, linked compartments differ in the subject-to-subject variation associated with $\mathrm{C}[\mathrm{r}]$ and $\mathrm{g}[\mathrm{r}]$ estimates. The lowest levels of variation are found for capillary-podocytes and capillary-urinary space $(\mathrm{C}[\mathrm{r}]$ average $\mathrm{CV}=19 \%$ and $26 \%$ respectively; $\mathrm{g}[\mathrm{r}]$ average $\mathrm{CV}=8 \%$ and $9 \%$ respectively). Intermediate levels of variation are found for capillary-mesangium $(\mathrm{CV}=28 \%$ for $\mathrm{C}[\mathrm{r}]$ and $13 \%$ for $\mathrm{g}[\mathrm{r}]$ ) and the highest values for mesangium-podocytes, mesangium-urinary space and podocytes-urinary space $(\mathrm{C}[\mathrm{r}]$ average $\mathrm{CV}=34-52 \%$; $\mathrm{g}[\mathrm{r}]$ average $\mathrm{CV}=17-30 \%)$.

Table 1. The cross covariances, C[r], and cross correlation functions, $g[r]$, for tissue compartments (capillary, mesangium, podocyte and urinary space) of renal corpuscles analysed at varying dipole distances, $r$. Values are given as group means $(\mathrm{CV})$ for $n=9$ rats. The expected values of $C[r]$ and $g[r]$ for 'random' interactions (neither attraction nor repulsion) are also indicated.

\begin{tabular}{|c|c|c|c|c|c|c|c|c|c|c|c|c|}
\hline \multirow{2}{*}{$\begin{array}{c}\text { Dipole } \\
\text { Distance, } \\
\mathrm{r} \text { in } \mu \mathrm{m}\end{array}$} & \multicolumn{2}{|c|}{$\begin{array}{l}\text { Capillary- } \\
\text { mesangium }\end{array}$} & \multicolumn{2}{|c|}{ Capillary-podocyte } & \multicolumn{2}{|c|}{$\begin{array}{c}\text { Capillary-urinary } \\
\text { space }\end{array}$} & \multicolumn{2}{|c|}{$\begin{array}{l}\text { Mesangium- } \\
\text { podocyte }\end{array}$} & \multicolumn{2}{|c|}{$\begin{array}{c}\text { Mesangium-urinary } \\
\text { space }\end{array}$} & \multicolumn{2}{|c|}{$\begin{array}{c}\text { Podocyte-urinary } \\
\text { space }\end{array}$} \\
\hline & $\mathrm{C}[\mathrm{r}]$ & $\mathrm{g}[\mathrm{r}]$ & $\mathrm{C}[\mathrm{r}]$ & $\mathrm{g}[\mathrm{r}]$ & $\mathrm{C}[\mathrm{r}]$ & $\mathrm{g}[\mathrm{r}]$ & $\mathrm{C}[\mathrm{r}]$ & $\mathrm{g}[\mathrm{r}]$ & $\mathrm{C}[\mathrm{r}]$ & $\mathrm{g}[\mathrm{r}]$ & $\mathrm{C}[\mathrm{r}]$ & $\mathrm{g}[\mathrm{r}]$ \\
\hline 3.97 & $\begin{array}{l}0.042 \\
(26 \%)\end{array}$ & $\begin{array}{c}0.78 \\
(21 \%)\end{array}$ & $\begin{array}{l}0.086 \\
(36 \%)\end{array}$ & $\begin{array}{c}0.83 \\
(8 \%)\end{array}$ & $\begin{array}{l}0.055 \\
(25 \%)\end{array}$ & $\begin{array}{l}0.76 \\
(8 \%)\end{array}$ & $\begin{array}{l}0.026 \\
(31 \%)\end{array}$ & $\begin{array}{c}1.02 \\
(22 \%)\end{array}$ & $\begin{array}{l}0.013 \\
(26 \%)\end{array}$ & $\begin{array}{c}0.85 \\
(24 \%)\end{array}$ & $\begin{array}{c}0.042 \\
(39 \%)\end{array}$ & $\begin{array}{c}1.21 \\
(15 \%)\end{array}$ \\
\hline 7.94 & $\begin{array}{l}0.057 \\
(22 \%)\end{array}$ & $\begin{array}{c}1.07 \\
(19 \%)\end{array}$ & $\begin{array}{l}0.123 \\
(17 \%)\end{array}$ & $\begin{array}{l}1.04 \\
(9 \%)\end{array}$ & $\begin{array}{l}0.074 \\
(25 \%)\end{array}$ & $\begin{array}{l}1.02 \\
(9 \%)\end{array}$ & $\begin{array}{l}0.027 \\
(40 \%)\end{array}$ & $\begin{array}{c}1.01 \\
(19 \%)\end{array}$ & $\begin{array}{l}0.013 \\
(35 \%)\end{array}$ & $\begin{array}{c}0.89 \\
(41 \%)\end{array}$ & $\begin{array}{l}0.034 \\
(45 \%)\end{array}$ & $\begin{array}{c}0.97 \\
(13 \%)\end{array}$ \\
\hline 11.91 & $\begin{array}{l}0.055 \\
(25 \%)\end{array}$ & $\begin{array}{c}1.01 \\
(10 \%)\end{array}$ & $\begin{array}{l}0.122 \\
(16 \%)\end{array}$ & $\begin{array}{l}1.03 \\
(8 \%)\end{array}$ & $\begin{array}{l}0.070 \\
(30 \%)\end{array}$ & $\begin{array}{c}0.96 \\
(11 \%)\end{array}$ & $\begin{array}{l}0.027 \\
(30 \%)\end{array}$ & $\begin{array}{l}1.04 \\
(11 \%)\end{array}$ & $\begin{array}{l}0.015 \\
(32 \%)\end{array}$ & $\begin{array}{c}0.99 \\
(23 \%)\end{array}$ & $\begin{array}{l}0.037 \\
(50 \%)\end{array}$ & $\begin{array}{c}1.05 \\
(12 \%)\end{array}$ \\
\hline 15.88 & $\begin{array}{l}0.055 \\
(28 \%)\end{array}$ & $\begin{array}{l}1.01 \\
(8 \%)\end{array}$ & $\begin{array}{l}0.125 \\
(14 \%)\end{array}$ & $\begin{array}{l}1.06 \\
(6 \%)\end{array}$ & $\begin{array}{l}0.070 \\
(24 \%)\end{array}$ & $\begin{array}{c}0.97 \\
(10 \%)\end{array}$ & $\begin{array}{l}0.026 \\
(25 \%)\end{array}$ & $\begin{array}{c}1.01 \\
(11 \%)\end{array}$ & $\begin{array}{l}0.017 \\
(44 \%)\end{array}$ & $\begin{array}{c}1.06 \\
(24 \%)\end{array}$ & $\begin{array}{c}0.033 \\
(68 \%)\end{array}$ & $\begin{array}{c}0.89 \\
(20 \%)\end{array}$ \\
\hline 19.85 & $\begin{array}{l}0.055 \\
(28 \%)\end{array}$ & $\begin{array}{c}0.99 \\
(10 \%)\end{array}$ & $\begin{array}{l}0.120 \\
(18 \%)\end{array}$ & $\begin{array}{l}1.01 \\
(9 \%)\end{array}$ & $\begin{array}{l}0.072 \\
(29 \%)\end{array}$ & $\begin{array}{c}0.99 \\
(10 \%)\end{array}$ & $\begin{array}{l}0.024 \\
(23 \%)\end{array}$ & $\begin{array}{c}0.96 \\
(15 \%)\end{array}$ & $\begin{array}{l}0.016 \\
(42 \%)\end{array}$ & $\begin{array}{c}1.04 \\
(30 \%)\end{array}$ & $\begin{array}{c}0.035 \\
(51 \%) \\
\end{array}$ & $\begin{array}{c}0.99 \\
(20 \%)\end{array}$ \\
\hline 23.82 & $\begin{array}{c}0.052 \\
(30 \%)\end{array}$ & $\begin{array}{c}0.94 \\
(10 \%)\end{array}$ & $\begin{array}{c}0.120 \\
(16 \%)\end{array}$ & $\begin{array}{l}1.01 \\
(6 \%) \\
\end{array}$ & $\begin{array}{c}0.073 \\
(27 \%)\end{array}$ & $\begin{array}{l}1.00 \\
(9 \%) \\
\end{array}$ & $\begin{array}{c}0.024 \\
(34 \%)\end{array}$ & $\begin{array}{c}0.93 \\
(26 \%) \\
\end{array}$ & $\begin{array}{c}0.016 \\
(30 \%)\end{array}$ & $\begin{array}{c}1.07 \\
(25 \%)\end{array}$ & $\begin{array}{c}0.035 \\
(48 \%)\end{array}$ & $\begin{array}{c}1.00 \\
(16 \%)\end{array}$ \\
\hline 27.79 & $\begin{array}{c}0.057 \\
(32 \%)\end{array}$ & $\begin{array}{c}1.04 \\
(13 \%)\end{array}$ & $\begin{array}{c}0.112 \\
(17 \%)\end{array}$ & $\begin{array}{c}0.95 \\
(10 \%)\end{array}$ & $\begin{array}{c}0.071 \\
(22 \%)\end{array}$ & $\begin{array}{c}0.99 \\
(10 \%)\end{array}$ & $\begin{array}{c}0.026 \\
(48 \%)\end{array}$ & $\begin{array}{c}0.97 \\
(30 \%) \\
\end{array}$ & $\begin{array}{c}0.016 \\
(28 \%)\end{array}$ & $\begin{array}{c}1.12 \\
(44 \%)\end{array}$ & $\begin{array}{c}0.034 \\
(53 \%)\end{array}$ & $\begin{array}{c}0.95 \\
(22 \%)\end{array}$ \\
\hline 31.76 & $\begin{array}{c}0.057 \\
(28 \%)\end{array}$ & $\begin{array}{c}1.06 \\
(10 \%)\end{array}$ & $\begin{array}{c}0.113 \\
(17 \%)\end{array}$ & $\begin{array}{c}0.96 \\
(8 \%)\end{array}$ & $\begin{array}{c}0.072 \\
(26 \%)\end{array}$ & $\begin{array}{c}0.99 \\
(10 \%)\end{array}$ & $\begin{array}{c}0.025 \\
(45 \%)\end{array}$ & $\begin{array}{c}0.96 \\
(29 \%)\end{array}$ & $\begin{array}{c}0.015 \\
(29 \%)\end{array}$ & $\begin{array}{c}1.02 \\
(27 \%)\end{array}$ & $\begin{array}{c}0.035 \\
(45 \%)\end{array}$ & $\begin{array}{c}1.00 \\
(14 \%)\end{array}$ \\
\hline 35.73 & $\begin{array}{c}0.054 \\
(30 \%)\end{array}$ & $\begin{array}{c}0.99 \\
(10 \%)\end{array}$ & $\begin{array}{c}0.122 \\
(16 \%)\end{array}$ & $\begin{array}{c}1.03 \\
(10 \%)\end{array}$ & $\begin{array}{c}0.070 \\
(24 \%)\end{array}$ & $\begin{array}{c}0.98 \\
(8 \%)\end{array}$ & $\begin{array}{c}0.025 \\
(33 \%)\end{array}$ & $\begin{array}{c}0.96 \\
(16 \%)\end{array}$ & $\begin{array}{c}0.017 \\
(37 \%)\end{array}$ & $\begin{array}{c}1.06 \\
(21 \%)\end{array}$ & $\begin{array}{c}0.034 \\
(49 \%)\end{array}$ & $\begin{array}{c}0.96 \\
(15 \%)\end{array}$ \\
\hline 39.70 & $\begin{array}{c}0.054 \\
(27 \%)\end{array}$ & $\begin{array}{c}0.99 \\
(11 \%)\end{array}$ & $\begin{array}{c}0.119 \\
(15 \%)\end{array}$ & $\begin{array}{l}1.01 \\
(8 \%)\end{array}$ & $\begin{array}{c}0.075 \\
(28 \%)\end{array}$ & $\begin{array}{l}1.03 \\
(8 \%)\end{array}$ & $\begin{array}{l}0.026 \\
(25 \%)\end{array}$ & $\begin{array}{c}1.04 \\
(15 \%)\end{array}$ & $\begin{array}{c}0.014 \\
(38 \%)\end{array}$ & $\begin{array}{c}0.93 \\
(30 \%)\end{array}$ & $\begin{array}{c}0.032 \\
(61 \%)\end{array}$ & $\begin{array}{c}0.88 \\
(19 \%)\end{array}$ \\
\hline Expected & 0.055 & 1.00 & 0.121 & 1.00 & 0.074 & 1.00 & 0.026 & 1.00 & 0.016 & 1.00 & 0.035 & 1.00 \\
\hline
\end{tabular}




\section{DISCUSSION}

The present study has focussed on the estimation of covariance and correlation functions which describe the spatial interactions between different compartments of a complex, multi-component structure, the renal corpuscle. Using linear dipole probes (Reed and Howard, 1999), analysis has shown that compartment interactions are neither clustered nor hyperdisperse over dipole distances which encompass the range from cell size to corpuscle size (Bertram, 1995; Mayhew, 1999b). Results also demonstrate substantial differences in interindividual variation for cross covariance and correlation functions associated with alternative compartment interactions. Less variability was noted for those combinations which included glomerular capillaries.

The renal corpuscle is an important functional unit of kidney morphology which filters blood perfusing its capillary bed. The process is referred to as ultrafiltration since passage of plasma molecules greater than about $8 \mathrm{~nm}$ in diameter or $70 \mathrm{kDa}$ in mass is usually precluded. The structural substrate of this process is the ultrafiltration barrier, a tissue composite of vascular endothelium, basal lamina and the foot processes of visceral epithelial cells which cover the basal lamina on its urinary aspect. Associated with the capillary bed is a meshwork of connective tissue made up of mesangial cells and extracellular matrix ingredients which they produce.

Previous studies on the principal tissue compartments of the rat renal corpuscle have examined spatial associations within compartments using covariance and pair correlation functions (Mayhew et al., 1999b). These studies showed that compartments display different patterns of spatial organisation with mesangium and urinary space being more tightly clustered than capillaries or podocytes at relatively short distances $(<8 \mu \mathrm{m})$. At greater distances, compartments exhibit neither clustering nor hyperdispersion. The same patterns were detected in corpuscles from experimental diabetic rats (Mayhew et al., 1999b). These studies also emphasised the relative invariance of corpuscle structure and this is consistent with results of similar analyses undertaken using cells (Mayhew, 1999a), glands (Mattfeldt et al., 1993a,b) and organs (Reed and Howard, 1999).

The present results, based on cross covariances and cross correlation functions, now demonstrate that compartmental interactions are similarly free of significant attraction or repulsion. Of further note is the finding that cross covariances and correlation functions differed in their observed subject-to-subject variation. To some degree, this reflects the variation in the volume densities of the individual compartments which contribute to each set of linked compartments and the variation within linked compartments which can be attributed to the fact that dipole counts decline as distances increase. However, it probably also reflects the functional and structural integration evident at the level of the ultrafiltration barrier (capillary-podocyteurinary space) and the perivascular nature of mesangium. Without further detailed analysis, including theoretical variances from null-hypothesis-model assumptions and consideration of the results of repeat measurements on different corpuscles from the same individuals, the possible explanations cannot be clearly resolved. The lowest levels of inter-subject variation were found for the following sets of compartment: capillary-podocyte, capillary-urinary space and capillary-mesangium. These compartments are functionally integrated but the volume densities of capillaries $(51 \%)$ are greater than those of the other compartments (11-24\%) and show less inter-subject variation (CVs $15 \%$ versus 23-28\%). Higher levels of inter-subject variation were seen for mesangiumpodocyte and mesangium-urinary space and these compartments are not linked functionally or architecturally and display smaller volume densities and larger coefficients of variation.

In conclusion, the present findings emphasise the constancy of biostructure within the renal corpuscle and the wisdom of monitoring not only the mean values of covariances and correlation functions but also their subject-to-subject variability.

\section{ACKNOWLEDGEMENTS}

I am grateful to Dr MG Reed (Liverpool) for software and sound practical advice. Specimen collection and preparation were undertaken with support from the Anatomical Society of Great Britain and Ireland.

\section{REFERENCES}

Baddeley AJ, Howard CV, Boyde A, Reid S (1987). Threedimensional analysis of the spatial distribution of particles using the tandem-scanning reflected light microscope. Acta Stereol 6(Suppl. II):87-100.

Bertram JF (1995). Analyzing renal glomeruli with the new stereology. Intern Rev Cytol 161:111-72.

Cruz-Orive LM (1976). Quantifying 'pattern': a stereological approach. J Microsc 107:1-18.

Cruz-Orive LM (1989). Second-order stereology: estimation of second moment volume measures. Acta Stereol 8:641-6. 
Evans SM, Gundersen HJG (1989). Estimation of spatial distributions using the nucleator. Acta Stereol 8:395-400.

Fricout G, Cullen-McEwen LA, Harper IS, Jeulin D, Bertram JF (2002) A quantitative method for analysing 3-D branching in embryonic kidneys: development of a technique and preliminary data. Image Anal Stereol 21:37-42.

Greco A, Jeulin D, Serra J (1979). The use of the texture analyser to study sinter structure: application to the morphology of calcium ferrites in basic sinters of rich iron ores. J Microsc 116:199-211.

Gundersen HJG, Jensen EB (1985). Stereological estimation of the volume-weighted mean volume of arbitrary particles observed on random sections. J Microsc 138:127-42.

Jackson MR, Mayhew TM, Haas JD (1988). On the factors which contribute to thinning of the villous membrane in human placentae at high altitude. II. An increase in the degree of peripheralization of fetal capillaries. Placenta 9:9-18.

Jensen EB, Kieu K, Gundersen HJG (1990). Second-order stereology. Acta Stereol 9:15-35.

Mattfeldt T, Frey H, Rose C (1993a). Second-order stereology of benign and malignant alterations of the human mammary gland. J Microsc 171:143-51.

Mattfeldt T, Schmidt V, Reepschläger D, Rose C, Frey H (1996). Contact centred density functions for the statistical analysis of random sets. A stereological study on benign and malignant glandular tissue using image analysis. J Microsc 183:158-69.

Mattfeldt T, Vogel U, Gottfried H-W, Frey H (1993b). Second-order stereology of prostatic adenocarcinoma and normal prostatic tissue. Acta Stereol 12: 203-208.
Mayhew TM (1999a). Quantitative description of the spatial arrangement of organelles in a polarised secretory epithelial cell: the salivary gland acinar cell. J Anat 194:279-85.

Mayhew TM (1999b). Second-order stereology and ultrastructural examination of the spatial arrangements of tissue compartments within glomeruli of normal and diabetic kidneys. J Microsc 195:87-95.

Mayhew TM, Bowles C, Orme G (2000). A stereological method for testing whether or not there is random deposition of perivillous fibrin-type fibrinoid at the villous surface: description and pilot applications to term placentae. Placenta 21:684-92.

Mayhew TM, Lucocq JM, Griffiths G (2002) Relative labelling index: a novel stereological approach to test for non-random immunogold labelling of organelles and membranes on transmission electron microscopy thin sections. J Microsc 205:153-64.

Mayhew TM, Wadrop E (1994). Placental morphogenesis and the star volumes of villous trees and intervillous pores. Placenta 15:209-217.

Reed MG, Howard CV (1998). Surface-weighted star volume: concept and estimation. J Microsc 190:350-6.

Reed MG, Howard CV (1999). Stereological estimation of covariance using linear dipole probes. J Microsc 195:96-103.

Serra J (1982). Image Analysis and Mathematical Morphology. Academic Press, London.

Stoyan D, Kendall WS, Mecke J (1995). Stochastic Geometry and Its Applications. $2^{\text {nd }}$ Edition. Wiley, Chichester.

Vesterby A, Gundersen HJG, Melsen F (1989). Star volume of marrow space and trabeculae of the first lumbar vertebra: sampling efficiency and biological variation. Bone 10:7-13. 